\title{
ANALISIS FAKTOR YANG MEMPENGARUHI KEPATUHAN MASYARAKAT MENGIKUTI PROGRAM POMP FILARIASIS
}

\author{
${ }^{1}$ Omay Rohmana, ${ }^{2}$ Badriah, \& ${ }^{3}$ Komarudin \\ ${ }^{1,2,3}$ Staf Dosen Poltekkes Kemenkes Tasikmalaya
}

\begin{abstract}
Abstrak
Tujuan penelitian adalah melakukan analisis faktor-faktor yang mempengaruhi kepatuhan masyarakat mengikuti program pemberian obat masal pencegahan (pomp) filariasis di Wilayah Puskesmas Maleber Kabupaten Kuningan. Desain penelitian adalah kuantitatif dengan pendekatan cross sectional study. Populasi sebanyak 42.167 orang dengan ukuran sampel sebanyak 240 orang. Teknik pengambilan sampel stratified random sampling. Teknik pengumpulan data melalui wawancara. Analisa data Analisa bivariate menggunakan chi square dan analisa multivariate dengan regresi logistik. Variable motivasi ( $p 0.006)$, derajat perubahan gaya hidup ( $p 0.049$ ), nilai/keyakinan mengurangi ancaman sakit $(0.000)$, pemahaman terhadap tingkah laku specific yang harus dilakukan (0.000), derajat kesukaran menerima dan melaksanakan instruksi (0.000), keyakinan terhadap terapi / instruksi (0.000), kekhawatiran terhadap efek samping obat (0.020), dan derajat kepuasan terhadap pelayanan kesehatan (0.022), memiliki nilai $p<$ dari 0.05 , sehingga dapat disimpulkan, bahwa variabel tersebut memiliki pengaruh terhadap kepatuhan masyarakat mengikuti program POMP filariasis. Factor dominan yang mempengaruhi kepatuhan masyarakat mengikuti program POMP filariasis adalah nilai/keyakinan mengurangi ancaman sakit dengan nilai Exp (B) paling tinggi, yaitu 4.251. Perencanaan dan alokasi anggaran, dan pelaksanaan kegiatan promosi / pendidikan kesehatan khususnya program POMP filariasis perlu dtingkatkan. Perlu dilakukan penelitian yang bertujuan untuk mencari metoda/pendekatan maupun media yang lebih efektif dalam pelaksanaan promosi dan pendidikan kesehatan kepada masyarakat
\end{abstract}

Kata Kunci: factor-faktor, kepatuhan, POMP filariasis

\begin{abstract}
The purpose of research is to analyze the factors that affecting the community compliance to prevention of mass drug administration (Pomp) filariasis program in Kuningan. The study design was quantitative with cross sectional study. The population of 42,167 people with a sample size of 240 people. The sampling technique stratified random sampling. Data collection through interviews. The data analysis bivariate analysis using chi square and multivariate logistic regression analysis. Variable motivation ( $p$ 0.006), the degree of change in lifestyle ( $p$ 0.049), value / belief reduce the threat of illness (0.000), the understanding of the behavior specific to do (0.000), the degree of difficulty of receiving and executing instructions (0.000), belief in therapy / instruction (0.000), concerns about adverse effects of drugs (0.020), and the degree of satisfaction with health services (0.022), $p<0.05$, so it can be concluded that these variables have an influence on the compliance of the public to follow the program POMP filariasis. The dominant factor affecting the compliance community POMP filariasis program is the value/belief reduce the threat of illness with $\operatorname{Exp}(B)$ the highest, is 4,251.
\end{abstract}

Keyword: factors, compliance, POMP filariasis

\section{PENDAHULUAN}

Filariasis merupakan jenis penyakit yang disebabkan oleh infeksi parasit nematode. Di daerah-daerah endemik, $80 \%$ penduduk bisa mengalami infeksi tetapi hanya sekitar $10-20 \%$ populasi yang menunjukan gejala klinis. Infeksi parasit ini tersebar didaerah tropis dan sub tropis seperti Afrika, Asia pasifik selatan, dan Amerika selatan. Diseluruh dunia angka perkiraan infeksi filaria mencapai 250 juta orang. Di Asia, filaria endemik terjadi di 
Indonesia, Myanmar, India dan Srilangka (Widoyono, 2011).

Penyakit ini merupakan salah satu masalah kesehatan masyarakat yang serius di Indonesia. Tahun 2009 penduduk berisiko tertular filariasis lebih dari 125 juta orang yang tersebar di 337 kabupaten/kota endemis filariasis dengan 11.914 kasus kronis yang dilaporkan dan diestimasikan prevalensi microfilaria 19\%. (Ditjen PP \& PL, 2010). Profil kesehatan Propinsi Jawa Barat tahun 2013, menunjukkan Kabupaten Kuningan merupakan wilayah dengan jumlah penderita filariasis mencapai 4,67\% dan menempati urutan ke 10 tertinggi yang ada di Propinsi Jawa Barat (Dinas Kesehatan Propinsi Jabar, 2013)

Penyakit ini dapat merusak sistem linfe, menimbulkan cacat seumur hidup serta stigma social bagi penderita dan keluarganya. Secara tidak langsung, berdampak pada penurunan produktivitas kerja, beban keluarga, dan menimbulkan kerugian ekonomi bagi negara yang tidak sedikit. Hasil estimasi Kementerian Kesehatan (2009) menyebutkan bahwa kerugian ekonomi akibat filariasis setahun mencapai 43 trilyun rupiah jika tidak dilakukan program pengendalian filariasis (Ditjen PP \& PL, 2010)

Oleh karena itu, pemerintah bertekad mewujudkan Indonesia bebas Kaki Gajah Tahun 2020, dan dibutuhkan suatu rencana yang sistematis di tingkat Nasional untuk menanggulangi hal tersebut yaitu dengan menetapkan dua pilar kegiatan yang akan ditempuh. Pertama dengan memutuskan mata rantai penularan dengan Pemberian Obat Massal Pencegahan Filariasis (POMP filariasis) di daerah endemis dengan menggunakan DEC $6 \mathrm{mg} / \mathrm{kg}$ berat badan yang dikombinasikan dengan albendazole $400 \mathrm{mg}$ sekali setahun dan dilakukan minimal 5 tahun, dan kedua perawatan kasus klinis filariasis baik kasus klinis akut maupun kasus klinis kronis (Ditjen PP \& PL, 2010).
Sosialisasi dan pemberian informasi sebelum pelaksanaan program dilakukan oleh petugas kesehatan agar semua masyarakat yang menjadi sasaran dapat mengikuti anjuran / instruksi petugas. Tetapi pada kenyataannya tidak demikian, masih banyak masyarakat yang tidak datang dan tidak minum obat cacing filariasis. Hal tersebut dapat dilihat pada data cakupan POMP filariasis di Puskesmas Maleber Kabupaten Kuningan yang hanya sebesar $68,22 \%$ dan merupakan cakupan kedua terendah dari 37 puskesmas di Kabupaten Kuningan (Dinkes Kab. Kuningan, 2015).

Banyak faktor yang dapat menyebabkan hal tersebut, Kozier (1997) menyebutkan, diantaranya adalah pemahaman masyarakat mengikuti informasi dan instruksi yang diberikan, tidak yakin akan keberhasilan terapi, kekhawatiran mengikuti efek samping, dan sebagainya. Penelitian ini bertujuan untuk melakukan analisis faktor-faktor yang mempengaruhi kepatuhan masyarakat mengikuti program pemberian obat masal pencegahan (pomp) filariasis di Wilayah Puskesmas Maleber Dinas Kesehatan Kabupaten Kuningan

\section{METODE PENELITIAN}

Jenis penelitian ini analitik, dengan pendekatan cross sectional. Populasi penelitian adalah semua Warga yang tercatat pada sasaran program kegiatan POMP di wilayah Puskesmas Maleber Dinas Kesehatan Kab. Kuningan dengan jumlah 42.167 orang. Besar sampel penelitian ditentukan menggunakan rumus $n=Z^{2}{ }_{1-a / 2} p$ (1-p) $N / d^{2}(N-1)+Z^{2}{ }_{1-\alpha / 2} p(1-p)$ (Suyatno, 2010). Hasil perhitungan besar sampel minimal penelitian adalah 232,3 dibulatkan menjadi 240 orang. Teknik pengambilan sampel stratified random sampling. Analisis data bivariat dengan teknik chi kuadrat, dan analisis multivariat dengan teknik regresi logistik ganda. 
Tabel 1. Hasil Analisis Bivariat

\begin{tabular}{|c|c|c|c|c|c|}
\hline \multirow[b]{2}{*}{ Factor } & \multirow{2}{*}{\multicolumn{2}{|c|}{$\%$}} & \multirow[b]{2}{*}{ Nilai p } & \multicolumn{2}{|c|}{ 95\% Confidence Interval } \\
\hline & & & & Lower & Upper \\
\hline Motivasi & Baik & 78 & 0.006 & 0.000 & 0.020 \\
\hline Drjt Perubahan Gaya Hidup & Mudah & 66.7 & 0.049 & 0.029 & 0.088 \\
\hline Masalah Kesehatan & ada & 63.7 & 0.436 & 0.458 & 0.584 \\
\hline Nilai/Keyakinan Kurangi Anc. Skt & Yakin & 65.4 & 0.000 & 0.000 & 0.012 \\
\hline Pemahaman Thd T.Laku Specific & Paham & 73.1 & 0.000 & 0.000 & 0.012 \\
\hline Drjt Kesukrn terima \& laksanakan Inst. & Mudah & 50.8 & 0.000 & 0.000 & 0.012 \\
\hline Keyakinan Thd Terapi / Instruksi & Yakin & 77.9 & 0.000 & 0.000 & 0.012 \\
\hline Kekhawatiran Thd E. Samping Obat & khawatir & 50.8 & 0.020 & 0.008 & 0.050 \\
\hline Budaya Yg Mempersulit Kepatuhan & Tdk ada & 97.5 & 0.729 & 0.988 & 1.000 \\
\hline Drjt Kepuasan, Kualitas Yankes & Puas & 79.6 & 0.022 & 0.013 & 0.062 \\
\hline
\end{tabular}

Tabel 2. Hasil Analisis Multivariat

\begin{tabular}{|c|c|c|c|c|c|c|c|c|}
\hline \multirow[t]{2}{*}{ Variabel } & \multirow[t]{2}{*}{ B } & \multirow[t]{2}{*}{ S.E. } & \multirow[t]{2}{*}{ Wald } & \multirow[t]{2}{*}{ df } & \multirow[t]{2}{*}{ Sig. } & \multirow[t]{2}{*}{$\operatorname{Exp}(B)$} & \multicolumn{2}{|c|}{$\begin{array}{c}\text { 95\% C.I.for } \\
\text { EXP(B) }\end{array}$} \\
\hline & & & & & & & Lower & Upper \\
\hline motivasi(1) & -.447 & .575 & .606 & 1 & .436 & .639 & .207 & 1.972 \\
\hline drjt_prb_gh(1) & .389 & .539 & .520 & 1 & .471 & 1.475 & .513 & 4.239 \\
\hline nli_krg_anc_s(1) & 1.447 & .799 & 3.280 & 1 & .070 & 4.251 & .888 & 20.353 \\
\hline pmhm_thd_tl(1) & -.145 & .560 & .067 & 1 & .795 & .865 & .288 & 2.594 \\
\hline drjt_kskrn_trm(1) & -.327 & .450 & .526 & 1 & .468 & .721 & .298 & 1.743 \\
\hline kykñ_thd_trp(1) & -4.096 & .782 & 27.402 & 1 & .000 & .017 & .004 & .077 \\
\hline khwatr_efsam(1) & .062 & .451 & .019 & 1 & .891 & 1.064 & .440 & 2.572 \\
\hline drjt_kepuasn(1) & .043 & .519 & .007 & 1 & .933 & 1.044 & .378 & 2.888 \\
\hline
\end{tabular}

\section{HASIL PENELITIAN}

Berdasarkan tabel 1, dapat dilihat, bahwa variable motivasi, derajat perubahan gaya hidup, nilai/keyakinan mengurangi ancaman sakit, pemahaman terhadap tingkah laku specific yang harus dilakukan, derajat kesukaran menerima \& melaksanakan instruksi, keyakinan terhadap terapi / instruksi, kekhawatiran terhadap efek samping obat, dan derajat kepuasan terhadap pelayanan kesehatan memiliki nilai $\mathrm{p}<$ dari 0.05 , sehingga dapat disimpulkan, bahwa variabel tersebut memiliki pengaruh

\section{PEMBAHASAN}

\section{Motivasi}

Hasil peneltian menunjukkan, motivasi memiliki pengaruh terhadap kepatuhan masyarakat mengikuti program POMP filariasis ( $0.006<0.05)$. Kozier (1997), menyatakan bahwa seseorang patuh mengikuti suatu anjuran dipengaruhi oleh adanya motivasi. Dorongan berespon atau berprilaku positif dapat diakibatkan sebagai terhadap kepatuhan mengikuti program POMP filariasis.

Hasil analisis multivariate penelitian ini dapat dilihat sebagaimana pada tabel 2. Variable nilai/keyakinan yang mengurangi ancaman sakit, memiliki nila Exp (B) paling tinggi yaitu 4.251, sehingga dapat disimpulkan nilai/keyakinan yang mengurangi ancaman sakit merupakan factor dominan yang mempengaruhi kepatuhan masyarakat mengikuti program POMP filariasis.

hasil dari adanya proses belajar. Notoadmodjo (2010) dalam Utami (2015) menyatakan, adanya suatu tindakan seperti pendidikan kesehatan maupun promosi kesehatan akan menjadi stimulus rangsangan dalam diri seseorang, yang memungkinkan seseorang untuk mengambil suatu respon dan melahirkan reaksi tingkah laku. Hal ini sejalan dengan hasil penelitian Utami (2015) di daerah Subang Jawa Barat, 
dimana masyarakat yang sudah diberikan promosi kesehatan mempunyai sikap yang semakin baik yaitu $54,5 \%$.

\section{Derajat Perubahan Gaya Hidup}

Hasil penelitian menunjukkan, derajat perubahan gaya hidup mengikuti program POMP filariasismemiliki pengaruh yang bermakna terhadap kepatuhan mengikuti program POMP filariasis (p $0.049<0.05$ ). Hasil ini sejalan dengan pendapat Kozier (1997), bahwa derajat perubahan gaya hidup mempengaruhi kepatuhan. Azwar (1988), mengemukakan, bahwa perilaku kesehatan dipengaruhi oleh tingkat pendidikan, keadaan sosial budaya, dan sosial ekonomi yang baik, kebutuhan dan tutuntutan terhadap kesehatan relatif akan tinggi. Selain itu, sikap dan prilaku petugas kesehatan mempengaruhi prilaku masyarakat terhadap kesehatan, sebagaimana yang dikemukakan oleh Green (1980) dalam Notoatmojo (2010), bahwa pengetahuan dan sikap masyarakat terhadap kesehatan, termasuk petugas kesehatan mempengaruhi prilaku masyarakat dalam kesehatan.

\section{Masalah Kesehatan}

Hasil penelitian penunjukkan, variabel adanya masalah kesehatan tidak berpengaruh terhadap kepatuhan mengikuti program POMP filariasi ( $0.346>0.05$ ) Purwantyastuti (2010), mengungkapkan, seleksilah dengan cermat penduduk sasaran, pastikan pasien bukan penderita epilepsi, cirrhosis hepatis, penderita penyakit ginjal, tidak hamil, dan hipertensi. Pada orang dengan riwayat hipertensi, penyakit jantung dan penyakit ginjal yang dicurigai tidak terkontrol dengan baik, banyak hal dapat terjadi secara mendadak karena penyakitnya.

\section{Nilai/Keyakinan Mengurangi Ancaman Sakit}

Hasil analisis bivariate variabel Nilai / keyakinan yang diletakan dalam mengurangi ancaman sakit menunjukkan nilai p $0.000<$ 0.05 , ini berarti terdapat pengaruh yang bermakna antara nilai / keyakinan yang diletakkan dalam mengurangi ancaman sakit dengan kepatuhan mengikuti program
POMP filariasis dan pada analisa mutivariat, variabel ini merupakan variabel yang paling dominan dengan nilai Ekp. (B) paling tinggi yaitu 4.251. Hal ini mungkin dapat disebabkan telah terbentuknya keyakinan pada masyarakat, bahwa dengan mengikuti program POMP filariasis dapat menghindari atau mencegah dari penyakit filariasis, yang dampaknya sangat besar terhadap perekonomian dan penampilan penderita (kecacatan fisik) dimasa yang akan datang. Green (1980) dalam Notoatmojo (2010) menyatakan, bahwa kepercayaan masyarakat terhadap hal-hal yang berkaitan dengan kesehatan, system nilai yang dianut dapat mempengaruhi prilaku terhadap tuntuan prilaku kesehatan. Hal ini juga tidak lepas dari peran petugas kesehatan yang dapat meyakinkan, membina partisipasi, dan membina kerjasama dengan masyarakat dalam mensukseskan program POMP filariasis. Sebagaimana yang dikemukakan Ditjen PP \& PL Depkes RI (2009), bahwa peran petugas kesehatan adalah melakukan penyuluhan langsung ke masyarakat, menggalang kemitraan dengan kelompokkelompok potensial (organisasi wanita, PKK, agama, pemuda), dan memberdayakan kader dalam penemuan kasus, penyuluhan, dan kegiatan pengobatan masal.

Pemahaman pada Tingkah Laku Specifik

Hasil penelitianVariabel pemahaman terhadap tingkah laku specific yang harus dilakukan menunjukkan nilai p $0.000<$ 0.05.Semakin paham masyarakat terhadap instruksi atau anjuran, semakin meningkat kepatuhannya.Kozier (1997), bahwa kepatuhan dipengaruhi oleh pemahaman mayarakat terhadap instruksi / arahan yang diberikan oleh petugas kesehatan.Azwar (1995) menyatakan, bahwa Individu pada umumnya cenderung memiliki sifat yang konformis atau searah dengan sikap orang yang dianggap penting yang didorong oleh keinginan untuk berafiliasi dan keinginan.

\section{Derajat Kesukaran Menerima Terapi /} Instruksi

Hasil penelitian variabel derajat kesukaran menerima \& melaksanakan instruksi menunjukkan pengaruh terhadap 
kepatuhan mengikuti program POMP filariasis (p $0.000<0.05$ ). Kozier (1997), bahwa kesukaran menerima dan melaksanakan instruksi dari petugas mempengaruihi kepatuhan. Nurhayati (1997) yang dikutip oleh Hamdi (2001) menyatakan kepatuhan merupakan sifat patuh atau taat, ketaatan melakukan sesuatu yang dianjurkan. Skiner sebagaimana dikutip dalam Notoatmodjo (2010) menyatakan, bahwa faktor yang membedakan respon terhadap stimulus disebut determinan perilaku dan dibedakan menjadi dua, yakni determinan atau faktor internal, yakni karakteristik orang yang bersangkutan, yang bersifat given atau bawaan, misalnya tingkat kecerdasan, tingkat emosional, jenis kelamin, dan sebagainya, dan determinan atau faktor eksternal, yakni lingkungan, baik lingkungan fisik, sosial budaya, ekonomi dan sebagainya. Azwar (1988), bahwa respon terhadap terhadap stimulus dipengaruhi oleh tingkat pendidikan, keadaan sosial budaya, dan sosial ekonomi yang baik, kebutuhan dan tuntutan terhadap kesehatan relatif akan tinggi

\section{Keyakinan pada Terapi / Instruksi}

Hasil penelitian variabel Keyakinan terhadap terapi atau instruksi yang diberikan menunjukkan, bahwa variaebl ini mempengaruhi terhadap kepatuhan masyarakat mengikuti program POMP filariasis (p $0.000<0.05$ ). Hal ini sejalan dengan pendapat Kozier (1997) bahwa keyakinan terhadap terapi dan instruksi mempengaruhi kepatuhan. Upaya dalam rangka meningkatkan keyakinan masyarakat terhadap terapi maupun instruksi adalah melalui promosi/ pendidikan kesehatan. Utami (2015) mengemukakan, perlunya dilakukan promosi kesehatan maupun informasi tentang filariasis karena melihat fenomena yang ada di masyarakat, yaitu sebagian besar daerah endemis filariasis pada umumnya berada di dataran rendah, terutama di pedesaan, pantai, pedalaman, persawahan, rawa-rawa dan hutan secara umum. Masyarakat dengan karakteristik tersebut pada umumnya memiliki tingkat pendidikan yang lebih rendah dan ketaatan yang kuat pada nilai-nilai budaya yang berlaku. Supali (2010) menyatakan, eningkatan pemahaman penduduk tentang manfaat pengobatan masal menyebabkan cakupan makan obat pada penduduk meningkat sekitar $80 \%$.

\section{Kekhawatiran pada Efek Samping}

Hasil penelitian Variabel

Kekhawatiran terhadap efek samping Efek samping obat menunjukkan, variabel ini berpengaruh secara bermakna terhadap kepatuhan masyarakat mengikuti program POMP filariasis (p $0.020<0.05$ ). Hasil ini sesuai dengan pendapat Kozier (1997), bahwa kepatuhan dalam mengikuti program pengobatan dipengaruhi adanya kekhawatiran terhadap efek samping obat. Supali (2010), menyatakan kendala pengobatan masal yang banyak ditakuti petugas pelaksana lapangan seperti timbulnya demam, mual, muntah, pusing, sakit sendi dan badan, sebagai akibat dari bekerja obat dalam membunuh parasit harus disosialisasikan dengan jelas pada penduduk terlebih dahulu. Sakit yang ditimbulkan pada pemberian obat filaria dapat diatasi dengan pemberian obat balas oleh petugas medis atau paramedis yang telah disiapkan di lapangan untuk mengawasi jalannya pengobatan selama 3 hari. Purwantyastuti (2010), mengemukakan, bahwa setiap orang di daerah harus sudah paham tentang "apa dan mengapa" kejadian ikutan pasca pengobatan. Hal penting lainnya adalah pengertian dan kesadaran petugas kesehatan dan masyarakat bahwa kejadian ikutan yang tak enak ini jauh lebih ringan daripada efek penyakit filariasis yang menyebabkan kecacatan dan penderitaan seumur hidup.

\section{Derajat Kepuasan \& Kepuasan Pelayanan Kesehatan}

Hasil penelitian Variabel Derajat kepuasan, kualitas, hubungan dengan pelayanan kesehatan menunjukkan, nilai $p$ $0.022<0.05$ yang berarti variabel ini berpengaruh terhadap kepatuhan masyarakat mengikuti program POMP 
filariasis. Hasil ini sejalan dengan pendapat Kozier (1997) bahwa derajat kepuasan, kualitas, dan hubungan masyarakat dengan pelayanan kesehatan mempengaruhi kepatuhan masyrakat mengikuti anjuran. Green (1980) dalam Notoatmodjo (2010), bahwa sikap dan prilaku petugas kesehatan dapat menguatkan prilaku masyarakat terhadap kesehatan. Rowe (2005), menyatakan keteraturan / kepatuhan dipengaruhi antara lain jarak tempuh, pelayanan petugas kesehatan. $\mathrm{Hal}$ ini diperkuat dengan pendapat Subyantoro (2009), bahwa pekerjaan (kegiatan) yang secara instrinsik memberikan kepuasan lebih memotivasi bagi kebanyakan orang daripada pekerjaan (kegiatan) yang tidak memuaskan.

\section{KESIMPULAN}

Prosentasi responden yang memiliki motivasi baik $78 \%$, mudah melakukan peruabahan gaya hidup $66.7 \%$, yang memiliki masalah kesehatan $63 \%$, yang merasa yakin program POMP mengurangi ancaman sakit $65.4 \%$, yang paham terhadap tingkah laku specific yang harus dilakukan $71.3 \%$, yang mudah menerima \& melaksanakan instruksi $50.8 \%$, yang yakin terhadap terapi atau instruksi yang diberikan $77.9 \%$, yang khawatir terhadap efek samping $50.8 \%$, yang tidak memiliki budaya specific yang dapat menghambat mengikuti program POMP fialriasis $97.5 \%$, yang merasa puas terhadap pelayanan kesehatan $79.6 \%$, dan yang patuh mengikuti program POMP filariasis $77.5 \%$.

Variable motivasi ( $p$ 0.006), derajat perubahan gaya hidup (p 0.049), nilai/keyakinan mengurangi ancaman sakit (0.000), pemahaman terhadap tingkah laku specific yang harus dilakukan (0.000), derajat kesukaran menerima \& melaksanakan instruksi (0.000), keyakinan terhadap terapi / instruksi (0.000), kekhawatiran terhadap efek samping obat (0.020), dan derajat kepuasan terhadap pelayanan kesehatan $(0.022)$, memiliki nilai $\mathrm{p}<$ dari 0.05 , sehingga dapat disimpulkan, bahwa variabel tersebut memiliki pengaruh terhadap kepatuhan masyarakat mengikuti program POMP filariasis

Factor dominan yang mempengaruhi kepatuhan masyarakat mengikuti program POMP filariasis adalah nilai/keyakinan mengurangi ancaman sakit dengan nilai Exp (B) paling tinggi, yaitu 4.251

\section{SARAN}

1. Meningkatkan kegiatan promosi / pendidikan kesehatan kepada masyarakat khususnya berkaitan dengan program POMP filariasis.

2. Menggunakan berbagai media / saluran dan pendekatan dalam mensosialisasikan program POMP filariasis kepada masyarakat.

3. Meningkatkan peran serta masyarakat (pemerintahan setempat, tokoh masyarakat, pemuka agama, kader kesehatan, dsb) dalam upaya meningkatkan pemahaman dan partisipasi masyarakat dalam mengikuti program POMP filariasis.

\section{DAFTAR PUSTAKA}

Azwar. 2005. Sikap manusia teori dan pengukurannya. Yogyakarta. Pustaka Pelajar

Dinas Kesehatan Kabupaten Kuningan. 2015. Laporan cakupan Hasil Pelaksanaan POMP Filariasis di Kabupaten Kuningan. Tidak dipublikasikan.

Dinas Kesehatan Propinsi Jawa Barat. 2013. profil kesehatan jawa barat tahun 2013. Diunduh tanggal 30 Desember 2015

dari

http://www.diskes.jabarprov.go.id

Ditjen PP \& PL Depkes RI. 2009. Mengenal

Filariasis. Diunduh tanggal 28

Desember 2015 dari

http://www.pppl.depkes.go.id

Ditjen PP \& PL Kemenkes RI. 2010. Rencana Nasional Program Akselerasi Eliminasi Filariasis di Indonesia. Diunduh tanggal 28 Desember 2015 dari https://www.academia.edu

Hamdi. (2001). Faktor-Faktor yang Berhubungan dengan Kepatuhan 
Berobat Penderita TB Paru Pada Fase Intensif $\mathrm{Di}$ Kab. Majalengka Tahun 1997-2000. Tesis. Depok: FKM-UI. Diunduh tanggal 22-6-2011 dari http://eprints.lib.ui.ac.id

Kozier, B. Erb, G. \& Blais, K. (1997). Profesional Nursing Practice Concept and Perspective. California: Addison Wesley Longman

Notoatmodjo, S. $2010 . \quad$ Metodologi Penelitian Kesehatan, Jakarta: Rineka Cipta.

Purwantyastuti.2010. Pemberian Obat Massal Pencegahan (Pomp) Filariasis. Buletin Jendela Epidemiologi. Volume I Juli 2010. ISSN 2087-1546. Diunduh tanggal 28 Desember 2015 dari www.depkes.go.id

Rowe, et al. (2005). Adherence to TB Preventive Therapy for HIV-Positive Patients in Rural South Africa: Implications for Antiretroviral Delivery in Resource-poor Setting. International Journal Tuberculosis Lung Diseases 9 (3): 263-9

Subyantoro, A. 2009.Karakteristik individu, karakteristik pekerjaan, karakteristik organisasi dan kepuasan kerja pengurus yang dimediasioleh motivasi kerja (studi pada pengurus KUD di kabupaten sleman). Jurnal manajemen dan kewirausahaan. Vol 11 No. 1.
Maret 2009:11-19. Diunduh tanggal 1601-2016 dari http://puslit2.petra.ac.id/ejournal/index.p hp/man/article/viewfile/17740/177661

Supali, S. 2010. Keberhasilan Program Eliminasi Filariasis Di Kabupaten Alor, Nusa Tenggara Timur. Buletin Jendela Epidemiologi. Volume I Juli 2010.ISSN 2087-1546. Diunduh tanggal 28 Desember 2015 dari www.depkes.go.id

Suyatno. 2010. Menghitung Besar Sampel Penelitian Kesehatan Masyarakat. Diunduh tanggal 22 Agustus 2013 dari http://www.slideshare.net

Utami, N.W. 2015. Pengaruh Promosi Kesehatan Tentang Filariasis Terhadap Sikap Masyarakat Dalam Upaya Pencegahan Penyakit Filariasis di Daerah Pantura Kabupaten Subang.Naskah Publikassi Program Studi IImu Kesehatan Masyarakat Fakultas IImu Kesehatan Universitas Muhammadiyah Surakarta. Diunduh tanggal 28 Desember 2015 dari http://eprints.ums.ac.id/37138/2/2_Nask ah\%20Publikasi.pdf

Widoyono, 2011, Penyakit Tropis epidemiologi, Penularan, Pencegahan, dan Pemberantasan, Erlangga: Semarang. 